\title{
Ethnologies
}

\section{The Topography of The Female Self in Indian Therapeutic Cults}

\section{Marine Carrin}

Volume 33, numéro 2, 2011

URI : https://id.erudit.org/iderudit/1015023ar

DOI : https://doi.org/10.7202/1015023ar

Aller au sommaire du numéro

Éditeur(s)

Association Canadienne d'Ethnologie et de Folklore

ISSN

1481-5974 (imprimé)

1708-0401 (numérique)

Découvrir la revue

Citer cet article

Carrin, M. (2011). The Topography of The Female Self in Indian Therapeutic Cults. Ethnologies, 33(2), 5-28. https://doi.org/10.7202/1015023ar

\section{Résumé de l'article}

Les anthropologues ont souligné les relations qui existent entre les symptômes de souffrance, l'action rituelle et la possession involontaire. Cet article montre l'importance du langage et de la ritualisation dans deux cultes thérapeutiques de l'Inde. Le point crucial ici consiste à montrer comment le rite permet de représenter et de manipuler des états mentaux. Nous voyons comment des individus utilisent la possession pour reformuler leur rapport à eux-mêmes. La thérapie implique donc une prise de conscience de soi. 


\title{
The Topography of The Female Self in Indian Therapeutic Cults
}

\author{
Marine Carrin \\ Centre d'Anthropologie Sociale, Toulouse
}

In South Asia, women, like subaltern communities, tend to be muted in everyday discourse. In this paper, various modes of female expression will be discussed, as they are displayed in two possession cults, in Bengal and South Kanara. I am concerned here with how affects and emotions, embedded in cultural idioms, emerge through linguistic and pragmatic processes. ${ }^{1}$ Looking at rituals often regarded as therapeutic, idioms of distress are here interpreted as ethnopsychiatric phenomena (Nichter 1981: 379). ${ }^{2}$ While sharing some general assumptions of the psychologist, I shall avoid speaking in dyadic terms about the conscious and the unconscious.

To analyze the formulation of the self ${ }^{3}$ in these cults, I propose, following Crapanzano (1992) to study modalities of verbal interaction during, or between, possession episodes. Self-reflection becomes here a communicative experience that the anthropologist may grasp through processes of ritualization or internalization, which are not necessarily expressed verbally. The sense of self and the selfawareness of the person may be understood through the mental representation of one's own person as it is perceived, both consciously and unconsciously, by the actor.

According to Dumont (1985: 94) the Western conception of the self is characterized by individualism, while the non-Western self is

1. For a cross-cultural comparison between emotions in Europe and in India, see Lynch (1990).

2. Nichter uses the term distress to refer to a broad range of feelings including vulnerability, apprehension, suppressed anger and other anxiety states which "may otherwise take the form of an untenable social conflict or rebellion" (Nichter 1981: 403, note 2).

3. Society shapes the self through the medium of cultural terms. See Rosaldo (1984) who argues that culturally coded emotions contribute to the making of the subjectivities. 
permeated by holism, referring to society as a whole. In an influential article, Spiro (1993) argues that this bi-polar conception of self - one Western, one non-Western - is 'wildly overdrawn'. According to Dumont (1985), Marriott (1976) and others, ${ }^{4}$ the South Asian self is context-dependent, sociocentric, and lacking in autonomy (Spiro 1993: 115). Spiro (1993: 118) questions the validity of an analysis of the self which is derived from the analysis of cultural symbols, ${ }^{5}$ "so that the actor's subjectivities' are not explicitly investigated."

In this article, I ask whether self-awareness is possible through ritual, which leads me to consider the problem of culturally determined conceptions of the self in anthropological terms, beyond its obvious psychological content. The material is derived from fieldwork, mainly among the Santals, in Bengal and Orissa since1976, and from later work among the Tulus of coastal Karnataka. Apart from life stories, information was gathered about devotion, asceticism and possession (Carrin 1986, 1997, 1999a, 1999b, 2007).

In South Asia, the context which shapes life histories and allows for self-awareness is often pervaded by violence. Writing about "social suffering" in South Asia, several authors have drawn our attention to the fact that "one cannot draw a sharp line between collective and individual experiences of social violence" (Das and Kleinman 2000: 10). Social violence is certainly an important factor in the rituals I examine here: a Santal woman is considered dead by her family when she transgresses the rule of endogamy, while women in matrilineal Tulu society are faced with considerable structural violence.

I shall explore, then, how individuals may use possession as an alternative strategy to produce a reformulation of the self. Such reformulation is a long process, involving a tension between

4. Shweder and Bourne (1984: 190) maintain that there are differences between Indian and Western conceptions of the self: "In India this relationship is conceived as "sociocentric organic," so that "individual interests (are subordinated) to the good of the collectivity," whereas in the West, it is conceived as "egocentric reductionist," so that "society is imagined to have been created to serve the interests" of the autonomous individual conceived as "existing free of society yet living in society."

5. Thus, Geertz (1984: 134) uses symbolic forms to describe the actors' own sense of self. 
psycho-social conflicts and the individual. These rituals will lead us to culturally specific conceptions of the self, defined in anthropological terms. Nevertheless, some individuals do not cope with this particular conception of the self, and they have to provide an individual answer to this dilemma.

\section{Ritual as a scene for therapy}

The central place of ritual in human affairs is due to the intricate relationships it develops with art, such as drama, music and dance, as well as with myth and language. Psychologists have tried to explain the importance of ritual, stressing its impact on the emotions as well as, ultimately, on cognition. Some of them claim that ritual is a means, either for representing special mental states, or for manipulating them. Among anthropologists, Malinowski (1944) saw ritual - and myth - as a cultural force to resolve problems among groups as well as for individuals. Turner (1969) - with regard to rites of affliction among the matrilineal Ndembu - treated the symbols expressed in ritual as important clues to social dramas. Bateson (1936) too, assumed that emotions are a central element in ritual, showing, among the Iatmul, how participants are concerned by ritual action. He coined the term ethos for sentiments and their internal organization, related in dialectic terms to eidos, or what we should now call cognitive dynamics. Emotions often appear to have a basis in embodied experience, a link which seems to be universal.

There are various circumstances and symptoms according to which an individual's behaviour may be attributed to seizure caused by supernatural beings. Whenever signs of psychopathologies such as anorexia, self mutilation, speech disorder or other troubles are evident, religious specialists tend to be consulted to determine what kind of being has possessed the afflicted, and how to exorcize it.

Turning to religious therapy, I need to stress not only the importance of the interface between culture and personal experience, but also the transformative power of the idiom used by the patient when he or she talks about his or her own suffering, or expresses it through ritual. 
Physical illness is not necessarily opposed to psychological suffering; rather the two are often seen to intermingle in situations of crisis. Several anthropologists have stressed the relationship between symptoms of distress and ritual action, and unwanted possession appears central to this problem (Obeyesekere 1981). They argue that the majority of the possessed are women, who are denied the possibility of expressing themselves otherwise. The forms of violence that women experience in everyday life enable them, however, to assert themselves through a religious idiom, which, as we shall see, becomes one of the modalities of the "Indian self" (Mayaram 1999).

Moreover, Kakar (1978) ${ }^{6}$ and Obeyesekere (1981) agree that possessed individuals are characterized by a hysterical personality. But this interpretation reduces the phenomenon to western psychiatric categories. It may well be that South Asian culture provides for the expression of hysteria as offering the most natural display of inner conflicts. In his clinical work, Kakar (1999) has questioned the crosscultural validity of psychoanalysis and concludes that psychological modernity, the essence of individuality, is also found in traditional non-Western civilizations. His work shows that the mental life of his Hindu patients - mostly male, if we keep to his own examples - is often pervaded by the "maternal enthrallment" produced by the Indian Oedipal complex. But we know little about female Indian patients and even less about the psychic disorders that women experience in a matrilineal society, in spite of the pioneering study of Carstairs and Kapur (1976).

Several anthropologists have stressed the relationship between symptoms of distress and ritual action and treated unwanted possession as central to this problem (Obeyesekere 1981). We are talking here of situations where the state of the individual is attributed to possession or seizure by supernatural beings, seen to act without or against any intention on the part of the possessed.

I shall stress here the importance of language and performance in these rituals. As Tambiah forcefully argues in his article "The Power of Words" (1968), saying things may be a way of acting. A performative

6. Kakar (1984: 245) shows that for Indian patients the roots of desire and repulsion go further in time, into previous existences. Obeyesekere (1981) refers to the Freudian concept of hysteria. 
utterance does not simply describe a state of affairs but is supposed to bring one about. The qualification 'performative', in these ritual contexts, differs slightly from the sense Austin (1962) gave to the term, for, I argue, the performative efficacy of ritual utterances supposes a consensus on emotions which engage the bodies of the devotees as well as their speech. This is what Sax (2009: 50) shows, when analyzing possession among the Hindu castes of Central Himalayas by the devata (minor deity) Kachya. He suggests that the sentence: "I have no one," is used there like a shifter, ${ }^{7}$ to allow a collective identity to be created during the ritual performance.

I argue that not only speech, but also other, non-verbal events may act as shifters. They, too, encode meaning. ${ }^{8}$ Sometimes, however, this shift in meaning is not just shared by the participants in the ritual but also internalized by some of the main actors, as a message from the divinity. This implies that such events or messages enter the devotee's mind and emotions, and may effect a solution, for example, to the dilemma proposed by an oracle. ${ }^{9}$ I will explore modalities of verbal action in possession to construct an argument about the variability of relationship between language, feelings and the Indian topography of the self. The term topography here is meant to imply that the structuration of the Self is influenced by cultural ideas. Following Appadurai (1990: 93), I argue that this topography of the self is culturally pervaded by mythic frames and other culturally bound references. Or, as Kakar (1990: 443) puts it: "Cultural ideas and ideals, when manifested in their narrative form as myths, pervade the innermost experience of the self."

I shall analyze the utterances which are performed during, or between episodes of possession, at two levels. The first level, which can be considered as a performance, implies direct or indirect dialogues between the possessed person, the different deities, and sometimes

7. This concept was introduced by Jacobson (1963) in his analysis of language. Later Silverstein (1976) developed the use of the concept of shifter in linguistic description.

8. As happened in a case I have described elsewhere, when the assembled devotees suddenly saw one arm of the goddess' statue moving (Carrin 1997). The event, interpreted as a miracle, changed the status of the local cult, its sanctuary, and its priestess.

9. This further implies that in some cases, the devotee answers to the oracle or the god when she/or he feels he has resolved the dilemma. 
the healer or the person who monitors the trances. This discourse is ruled by conventions but allows, in some cases, the possessed person to revaluate her feelings, and thus eventually to reframe her life. This reframing may lead to improvisatory practices which depend on a "regulated topography of the self," understood as a dialectic between conventional speech, which conceals inner feelings, and muted feelings.

To illustrate and clarify this argument, I shall present some performative aspects of two types of possession, connected with healing powers among the Santals in Bengal and among the Tulus of South Kanara. The two regions differ strongly in terms of kinship and social organization. The Santals, a tribal society on the fringes of Bengal, are patrilineal and egalitarian, while the Tulu of South Kanara include a number of matrilineal castes, which were formerly ranked within traditional chiefdoms. In Bengal, healing rituals are found mainly at the popular level of Hinduism. In South Kanara, they are closely linked to the regional bhuta cults ${ }^{10}$ and sometimes to the old chiefdoms.

\section{Possession discourse at the fringe of the Hindu world}

In Bengal, the goddess manifests herself in multiple forms, which differ in the way they transform the devotee's life. In this region, possession is not considered a proper expression of female devotion. It is not consciously sought, but 'just happens', and since it is not really allowed for women, it tends to be interpreted as an exceptional religious experience: the call of the goddess Kali (Carrin 1997, 1999a: 116). The woman who is possessed, is usually suffering in some way. Typically, Kali may induce fits in a woman afflicted by a serious disease, a woman whose husband has left her or one who has had a miscarriage. Such suffering is rarely identified as mental trouble, though symptoms of psychic disorders may appear. But in case of violent fits, village opinion may label them as expressions of

10. Bhutas (also called daivas) are deities who are central to the religious cults of the Tulu speakers of South Kanara. They are often seen as deified humans, and their myths may be seen as 'foundation myths' - and as 'charter' in Malinowski's sense - in the culture of the region. Their links to the main gods of Hinduism are not obvious, but they are commonly seen as the 'people' (gana) of Shiva. See Carrin and Tambs-Lyche (2003). 
pagalmi, a Bengali term for madness. Often, the goddess torments the woman, until the deity receives a shrine and is offered a regular cult.

Generally, the woman herself does not seek possession unless she is encouraged and controlled by a priestess or a guru. Such priestesses are low caste ${ }^{11}$ or Santal women who have already acquired powers of possession. They tend to explain their powers by referring to their past suffering.

Among low caste women, the notion of bad karma is often used to explain misfortune. Events occurring in childhood, like the unexplained death of a parent, impinge on informants' memories, allowing them to interpret a posteriori other events as part of the same succession of karmic misfortunes. This attribution to a karmic influence, a central theme in Indian culture, aids the individual to break free from a feeling of personal agency. Unwanted, uncontrolled possession, interpreted as a return of such buried memories, ${ }^{12}$ emerges as guilt, formerly repressed.

In the cases I have observed, suffering generates shakti (cosmic power, seen as female) as in the life stories Margaret Egnor describes from Tamil Nadu. The power acquired "through suffering and servitude is a special case of the Hindu theory of tapas, ${ }^{13}$ where the individual accumulates a certain heat" (Egnor 1982: 17).

Santal women who become priestesses are often those who have transgressed the rule of tribal endogamy, which often happens when they have migrated from the village to work in kilns or mines. Having had an affair with a Hindu, they are excluded from Santal society and declared dead in their village where their agnates perform a mock funeral.

This is what happened to Parvati, a Santal woman who fell in love with a Brahman who deserted his wife and children. Parvati met Chand at a kiln where she worked as a coolie and he as a truck driver. They fell in love and were married at a shivaite shrine where

11. Such as Lohar (blacksmith caste), Bangi (sweeper), or Muci (shoemaker, leatherworker).

12. In psychoanalysis the buried memory is often concealed by what Freud calls "the screen memory."

13. Heat or energy normally produced through ascetic exercises. 
the guru gave them an amulet to seal their marriage. After a while, Parvati tended to forget her Hindu companion to concentrate her attention on the gods, mostly Siva, Kali or Manasa. Soon, she felt that Chand might have felt guilty, having lost his caste for her, while she herself had left her Santal identity behind, exposing herself and her brothers to the wrath of the tribal deities, the bonga. Troubled by these sources of conflict, Parvati started worshipping the goddess Kali, very popular in the region. Devotion to a personal deity, in India, has long been a means of expressing distress. In Parvati's case, it also provided a socially accepted way of distancing a stressful family situation. She feared, too, the vengeance of the tribal deities who had attacked her own parents in the past. It is at this stage that she became possessed by Kali.

For Parvati, the state of possession usually implies clouding of consciousness, skin anaesthesia to pain, and a change of voice. Generally, the possibility of recall to reality is present, though partial amnesia follows. Still, Parvati remembers what the goddess has told her and tries to relate the goddess' words to her suffering. This corresponds to what Teja et al. (1970) call the first degree of possession; the two other degrees are characterized by partial amnesia, partial anaesthesia and no change of voice or - for the third degree - by a possible immediate recall to reality and gaining attention. Other devotees, who do not become priestesses, show mild clouding and immediate recall to reality.

We may trace recurrent paths of belief in these stories: some women seem to overcome their grief, or shame, to reorient their personal crisis in a religious direction. These women, inspired by the goddess, are able to produce a religious discourse where they add Hindu symbols to their belief. These borrowed symbols are interpreted according to the orientation of the individual. Some are corporeal like the joto, "the matted hair" which is a male shivaite symbol; others are artefacts such as the trishul, the shivaite trident, linked to the acquisition of a therapeutic power which is used to drive away the malevolent deities during exorcism (husit).

Parvati's case shows how the calling of the goddess to her priesthood may imply a personal crisis through sexual ambiguity, since priesthood can be attained only through the loss of femininity. In 
fact, it was only when Parvati's hair grew in the shape of matted hair (joto), that she realised she had been called by the goddess. Despite the threat of the goddess who warned her in a dream, Parvati cut some locks and threw them angrily at the corner of the shrine, an element of counter-transference. But Chand, her companion, declared that the locks were moving by themselves. Then some neighbours came, and wondered at the miracle. A woman who was suffering from skin disease rubbed her arm against the locks, and was cured. Parvati's therapeutic powers were acknowledged, and she was now able to carry the trident in order to perform exorcism. But this spiritual gift was not easy to accept.

Parvati has managed to reorient her suffering around her devotion (bhakti) to the goddess with whom she is able to converse through trances and dreams. She explained to me "what Ma has told me" and how she has tried to comply with the divine orders. Yet, Parvati resisted when the goddess ordered her to leave her companion. "Ma," she protested, "I need somebody to help me perform your puja, I need somebody to receive the patients when I take care of you." Finally Chand, her companion, became the mentor of her trances and the impresario of her career. But, in this narrative, the fierce goddess gradually turns into a Mother of Compassion, a Vishnu Kali, a sublimate version of the self.

In the Hindu pantheon, male deities tend to be cool while goddesses are typically hot, implying that they can be fierce and dangerous. This pattern of male coolness and female heat is carried into ordinary thinking. The bloodthirsty goddess, who relates to women in the "hot" condition of menstruation and pregnancy, is pleased by the regular cooling offerings. The heat relates to the shakti of the goddess. States of temporary ritual pollution, such as those caused by menstruation and death, are associated with heat and possession. But the Vishnu Kali is a Kali tamed, whose heat is controlled.

When Parvati, the woman, finally wears the joto, she embodies in herself one aspect of the goddess' terrifying masculinity. Parvati wants to refuse to embody this phallic aspect of the goddess, since the matted hair (joto) spits fire. But finally she accepts, and discovers that 
she can neutralize this dangerous aspect of the goddess by increasing her own ascetic heat, tapas.

In my earlier work I developed the story of Parvati to show that the attitude of Chand, her companion who "sees" Parvati's first miracles, is crucial, as the possession dialogue is produced not only by the inner states of the possessed, but involves the public negotiation of utterances and gestures. Thus, when Parvati seizes the trishul and walks fiercely some devotees scream: "dig here!," referring to buried malevolent deities that can be exhumed, which is a Santal method of exorcism. This kind of script allows Parvati to reflect on her own trajectory.

Later, she makes me understand that she knows she cannot beget a child, as she has lost her menstrual cycle. The loss of femininity, as evidenced by the loss of the menstrual cycle, is interpreted, in these stories, as the gift of a new identity. A menstruating devotee would become much too hot if she were possessed, says Parvati. In the case of my Santal and Bengali material, only male medicine men (ojhas) may, by the symbolization of menstrual blood, express the powers and ambivalence of female sexuality when they offer some drops of the blood of their thighs, conceptualized as sitka mayam, "menstrual blood," to placate female ghosts (yuginis). During exorcism (husit) the ojha becomes feminized, since he pretends to mock the yuginis, seen as ispirits of women who died before marriage, or the curin, the ghosts of women who died during pregnancy. According to my ojha informants, the so-called menstrual blood is as powerful as Shiva's poison and is infused with shakti. This comparison may help us to understand why female priestesses cease to menstruate when they receive the joto. The loss of menstrual blood conceptualized as "hot" and dangerous may be seen as an ascetic step but in a way it is replaced by the matted hair "which is also burning."

In our story, Parvati feels reborn. She simply declares "now I don't need a child, since I am the child of the goddess." This sentence concludes a long process where she has been troubled by her loss of femininity, and expresses how she recasts her own identity by acknowledging her place in a spiritual lineage. The idiom of motherhood is recurrent in all these stories which relate how the goddess transfers shakti to her female devotees, as if shakti were a 
female substance passed from mother to daughter. This is a powerful metaphor for the transmission of religious powers, and such transfers work from the goddess towards her devotee but also, it seems, from a human mother to her daughter. In the latter case, the mother transfers the ability to get possessed. We have two types of transmission, seen as close parallels: goddess - shakti - child/devotee.

\section{Human mother - ability to be possessed - daughter}

When the human mother is absent, it is often the female guru, seen as the spiritual mother, who encourages the possession of the devotee, helping her to overcome her fear. At another level, the female guru may grant her the joto, transforming her disciple into a sexually ambivalent being (Carrin 1999: 121-122).

This remodelled self is expressed in religious terms, and we understand that merging with the goddess becomes, for Parvati, a way to conciliate her inner conflicts by identifying with the goddess. This identification has been publicly negotiated, as when Appadurai (1990: 109-10) shows how praise can make or break bonds between the speaker, the audience and its referent. For the audience, the proof of Parvati's powers is her ability to utter prophecies, to unveil the uncertainty of the future, to negotiate with the goddess other people's destinies. My other stories of women in Bengal do not show the same trajectory, but most of them try to project their personal emotional experience in a religious idiom where possession and signs given by the goddess play a central role.

These discursive strategies can be indexed by different speech patterns. Sometimes, the woman sticks to her symptom. This is the case of Jobra, a woman who develops psychosomatic illnesses and hangs around the shrine of Parvati but does not get the vision from the goddess (darshan) and does not succeed in reframing her story. In some cases, a woman gets a successful darshan, but she does not speak about her emotions directly and projects her feelings on the goddess. "Ma is very angry when she sees rich people abusing the poor," says Asula Devi, a woman of the Blacksmith caste. Two years later, Asula has become a tantric priestess able to produce a social message, distancing herself from her own emotions. One of her sister's sons, a boy of fourteen, was beaten to death by a rich Marwari merchant 
for whom he worked. One day, Asula takes the photo of the dead body of the adolescent, published in a local newspaper, and places it at the feet of the goddess. The gesture has a performative power: the photo is seen as a powerful symbol of shakti. Devotees come to the shrine to experience the vision of the goddess and cry over the dead body of the child, since this drama reflects their own oppression by the dominant castes.

These examples show that cultural notions about the emotionality of women can be expressed through the idiom of possession, which allows women to go beyond speaking for themselves by telling their inner feelings which they project on the goddess: "Ma does not like. $\mathrm{Ma}$ is angry at the employer who killed that boy" and so on. This discursive pattern becomes more complex when the woman's powers are acknowledged and her possession is interpreted publicly as the call of the goddess.

The details of the symptoms, events and causation may vary, but there are conditions that must be fulfilled in order to transform unwanted possession into a mystic call. Sometimes, the goddess manifests herself in her murti (statue) and while this manifestation produces, at first, a perceptual disorientation, it may later allow the possessed woman to reorient herself in a shared religious landscape which is experienced individually (Carrin 1999). The mystic calling introduces Parvati to a spiritual lineage, while Asula's reorientation aims at producing a social message.

These examples show that possession implies performative patterns of speech and gestures which allow the empowerment of the possessed women, on the condition that they lead to a reformulation of the self, which constructs a link between the person and the social, religious and political contexts.

\section{The cult of Siri in South Kanara}

I shall now turn to a regional, therapeutic cult of South Kanara. Among the possession cults of this Tulu-speaking area (Tulunadu), the Siri cult is the only one where the deity possesses her devotee - rather than a specialized medium or priest - directly. Possession by Siri is seen as a sign of election. The cult is rooted in the legend 
of Siri, a matrilineal ancestress of the Bunt community, which is the dominant caste in the region. At the main shrine, Brahman priests invoke Siri as a bhuta who, once upon a time, was a queen insulted and driven from her own kingdom due to the felony of her husband and uncles.

"Once there was an old man, Berma Alva, who was lamenting as he had no descent. One day, the god Bermeru came to his door, in the guise of a religious dancer. He explained that Alva's family deities (bhutas) had been neglected and so kept him from having children. Berma, following the dancer's instructions, renovated his family shrines. Then he asked Bermeru to grant him the boon of progeny. Bermeru replied that he would give him a child. Thus Siri was born, from a flower pod of areca nut palm (pingara). When she was five, her marriage was arranged with Kantha Alva, who spent Siri's dowry on his mistress, a prostitute, with whom he was in love.

When Siri later became pregnant, her husband neglected his obligation to let her return to her natal home. Siri's father inquired why she had not come, but the husband, instead of honouring his wife with the gift of a sari beyake - a term which means "desire" - presented her with a ragged sari belonging to his mistress, the prostitute. Siri, feeling humiliated, returned to her (paternal) home where she gave birth to a son, Kumara. But there was a curse predicting that the grandfather should not see his grandchild. One day, as he heard the baby cry, Berma Alva collapsed and died. Siri, having lost her only kin, wandered towards the South, where she met another man who asked to marry her. In an areca nut grove, she gave birth to a daughter Sonne. But as Siri buried the placenta, foxes came and ate it - a bad omen. That night, Siri blessed the land and disappeared; she went into maya - illusion - and became a bhuta.

When Sonne, in her turn, married she gave birth to twin girls, Abbaga and Darraga. But Sonne and her husband neglected their vow to Brahma. The god, disguised as a fortuneteller, came to their home and cursed them. He foretold that the twins would suffer deeply and quarrel as their parents had neglected their religious vow.

One day the parents went away, leaving the twins alone. During their absence, Brahma came disguised as a sage and opened the chest 
where the parents had locked the cene mane, ${ }^{14}$ prompting the children to play. Soon, they quarrelled and one hit the other over the head with the game board. One of the twins fell down dead. In terror of facing the parents after such a crime, the other twin jumped into a pond. When the parents returned they met the sage, who explained that the god had taken away what he had given."15

The legend of Siri shows how, in the matrilineal ${ }^{16}$ household, the control of purity and truth is in the hands of women. The Siri festival takes place annually on the full moon of paggu (February) in six different temples. ${ }^{17}$ The cult allows women to express their emotional reactions to their own family situation, in a dramatic mode. Cult members profess devotion to Shiva, but this is not directly linked to their participation in the cult. As thousands of people arrive at the temple, the Brahmans perform a first ritual to Shiva. The cult participants then form several dozen informal groups of women, led by four to five men dressed in red silk lungi (loincloth). The female devotees are grouped according to their status in the cult, while the experienced cult members, forming an inside circle, wear an orange sari, the novices are dressed in white and stand in the outside circle. The relatives of the novices are present on the occasion, and male kinsmen make vegetal offerings to Siri.

Siri is a female cult though the male priests, $k u m a r a,{ }^{18}$ control the trance of the women. Siri may be seen as a therapeutic ritual which successfully activates episodic memory, and the women stress that their participation has helped them overcome their sorrow. The Siri ritual stages a dialogue between devotees and the family of bhutas when, at first, the women lament loudly that they are Sonne, Abbage, Darrage or even Siri, while the Kumara, the priest who controls them, is possessed by Siri's son Kumara, the only male of that mythic family.

14. The cene is played with seeds called bittu (Indian coral tree). See Claus (1986) and Carrin (2007).

15. For a translation of the Siri epic, see Honko, Gowda, Honko and Ray (1998).

16. For a study of Tulu matrilineal family, see Claus (1971).

17. I have attended the Siri Cult mainly in Urumbottu, Hiriedka and in Punjalkatte though I have also visited some other places a number of times, such as Nandolige, where the twin sisters' tombs are venerated.

18. The priest is named after Kumara, the son of Siri. 
To train the novices to identify with the characters of the epic, some kumara stage rehearsals, which are not necessarily sanctioned by the temple authorities. In Punjalkatte, one of the centres of the cult, the kumara said he wanted to make the women "spit their guts," and talk of their marital conflicts or inheritance problems. Here, the kumara asked the novices many questions. Did they suffer? Did they feel anxiety at the idea of getting married? But the girls were not allowed to answer the questions directly; they had first to find a new identity in the family of Siri. They were complaining of physical ailments such as headache, nausea, lack of appetite but did not allude to possession or fits. Their relatives, on the other hand, complained that the girls had been seized by a bhuta, but hoped the novices would be able to identify with Siri during the trances. Thus, when possession by Siri, Sonne and the twin granddaughters is acknowledged, the fear of unwanted possession by a preta (ghost) disappears.

Becoming a novice in the Siri cult does not carry the stigma of unwanted possession. When the novices are married women, they generally complain of their inlaws in veiled terms. The cult of Siri mobilizes intensive emotions: the woman is invited to show her feelings in the guise of Siri. The Brahman priests first invoke Siri at the main shrine. Then the women, becoming possessed, start reciting the Siri epic poem. They close their eyes and swing their bodies slightly to reach possession. Then they start to call each other by kinship terms, since they are all possessed by the Siri family. After an hour of such mild possession, one of the novices may get a more violent fit, and then she will be asked by the main kumara who seems to control the women's trance: "Who are you ?" If she answers: "Siri" or "Sonne," the kumara pretends not to believe her and tells her she is possessed by a malevolent bhuta. The novice alludes to some episode of the myth and if this episode is congruent with her own family conflicts, she may jerk violently. She may, at this stage, complain of her male relatives, who have generally left for a teashop or to watch some popular drama staged on the side.

During the night, the ritual game of cenne is played by two performers, who are not professional mediums, enacting the twin sisters Abbage and Darrage. The girls, who should be unmarried twins, sit facing the audience on a platform in front of the temple, while a kumara sits between them. He asks them some questions about 
their birth, place of origin and family. By way of answering, the twin sisters sing a part of the Siri epic. During the singing of the cenne game, they get violently possessed. When the possession intensifies, the elder sister, Abbage, takes the game board and hits her sister's head. Darrage is supposed to fall dead. Before the murder the tension has been strong between the sisters, and the kumara seems unable to control the situation. After death has been enacted, the kumara retains the twins, and helps them return to a normal emotional state. The two girls follow the kumara, and join a group of cult members.

I shall now concentrate on the emotional discourse devotees produce when possessed. Not much is said directly by the woman, but the names and laments she utters implicitly designate the suffering. The emotional discourse is constrained by the mythic chart though women may choose to embody Siri or Sonne in the different episodes of the epics.

In the Siri cult, then, the women project their own suffering on the characters of the epic, while their laments are controlled by the male priests (kumara) who also monitor their trance. They distance themselves from their own grief by identifying with the mythical female characters, who embody the sufferings a woman may endure in the matrilineal family, more specifically the jealousy which tends to separate sisters and threaten family unity (Claus1975, 1986). The assumption that underlies possession is that the woman is oscillating between her brother and her husband, as Turner (1969) shows for the women in matrilineal Ndembu society. Today many families turn towards patrilinearity due to government pressure for patrilineal inheritance and resentment between kin has become salient.

Here possession is transformed into a seva, a religious service, which ties the girl in a spiritual engagement to the Siri deities. In the last ritual episode, the women enter - one by one - a "grave" made of areca leaves, and then share a funeral meal. This suggests that they must internalize the death of the twin sisters in order to leave their mythic embodiment and recover their own selves. This final ritual seems to allow women to leave behind the inner feelings which created the unwanted possession or the illness. The ritual allows the novices to express emotional reaction to family situations in a dramatic mode. 
It is striking that new brides, or girls who were just getting married, sometimes collapse from grief during the possession.

In the Siri ritual women are confronted with their own grief but also with its social source, the discordant relationships in the matrilignage. The ritual provides the women with a series of mirrors, where they can view their own distress through the epic scenario, and this mirror image may be shared by the women participating in the ritual. They do not have to renounce the world, or indulge in asceticism, to be cured, and they do not have to reorient their mental space, unlike the devotees who become priestesses in Bengal.

\section{Comparing the examples}

The discourse of the priestesses in Bengal, and the laments of the participants in the Siri cult, constitute two rather different discursive strategies, and they involve different speech patterns.

In Bengal, Parvati and Asula at first express their grief through unwanted possession, until the goddess imposes herself, allowing them to found a shrine. She also permits them to take some particular ritual initiatives, as when Parvati adopts the matted hair and the trishul, and when Asula starts meditating at the cremation ground. These practices are rooted in the religious frameworks of the region, but Parvati and Asula are able to reinterpret them, provided they can obtain acceptance, through negotiation, of their subjective expressions of emotion in public. This is what happens, for example, when a witness acknowledges a miracle, the locks of matted hair that move, in Parvati's case, or the arm of the goddess' statue which is seen to move, in the case of Asula. These initiatives stem from improvisation, and the results may not always have been foreseen. Thus, by means of the locks of her joto, Parvati cures a woman who suffers from a skin disease, while Asula succeeds in creating sentimental bonds between local people for whom the murder of a young boy has become a political issue. These improvisations are prepared, however, through verbal interaction and other referential practices, such as the reappropriation of accepted Hindu symbols. These examples from Bengal certainly show that women's access to marginal forms of priesthood allows public negotiation of suffering in Bengal. 
But what about the Tulu example? Are the Siri devotees victims of a rhetorical device, the chart of the ritual and the mythic scenario? Do these restrictions allow them only a limited self-expression, year after year? During the ritual, the verbal and gestural forms of protest against society remain ambiguous, since they agree to calm down under the control of the kumara. The Siri ritual, we may conclude, is finally oppressive, since the emotions of real life can only be expressed in veiled terms. Still, the ritual confers, on all female participants, the same kind of religious status.

In both regions, social violence experienced by women is both individual and collective. Relating female possession to the tensions faced by women, we may conclude that in Bengal, tribal or low caste women who suffer exclusion tend to appropriate and transform Hindu values such as bhakti in order to reorient their lives. That is why austerities allow Parvati to merge with the goddess, sublimating sexual and other drives so as to remodel herself as the child of the goddess. We may look at both cults as personalising strategies in search of an identification which encompasses the suffering. In Bengal, as well as in South Kanara, a divine figure is used by the possessed person to bridge the gap between the inner, repressed feelings and those which, muted, can only be expressed in veiled terms, as Abu-Lughod (1986) suggests in her analysis of Bedouin poetry.

A last question remains: are emotions necessarily gendered in South Asia? Possession is frequently interpreted as feminine, as Dimock (1966) underlines, and devotion is often expressed in a feminine idiom. Still we know, from other cases of marginal priesthood and mediumship, that possession often implies sexual conversion. In both Bengal and Karnataka, the medium should present both male and female characteristics in order to approach the goddess. Sexual conversion is less obvious in the case of the Siri ritual: like Abbage and Darrage, bhutas are often twins of the same sex who exemplify different kinds of emotions. Though twins represent an ideal cosmic totality, they are complementary rather than similar and each of them may offer us a divergent view of the same reality. Abbage and Darrage may represent the ideal sisters of the matrilineal family, but the epic shows how the twins do not form a harmonious pair, since rivalry and jealousy have pervaded their feelings. 
In Bengal as in Karnataka, ritual enables devotees to embody new identities, but while the Santal women must renounce the world to become priestesses, the devotees of Siri only release their inner tensions temporarily. Both rituals allow a certain amount of verbal and gestural expression to the devotees, though in the Siri cult their utterances become encapsulated in the limited dialogue they engage in with the Siri bhutas.

\section{Conclusion}

Let me return to our central question: can ritual produce selfawareness? I argue here that self-awareness is manifested when the ego views itself from the vantage point of the other. In possession episodes the other is represented by a divine figure which becomes a support of transference and counter-transference. One casts the other in order to cast oneself, since possession episodes become authorized ways to speak about one's self (Carrin 2009). The "other" who, at first, is often feared or even discarded, may represent an imaginary function, which can be embodied in real or imaginary beings - fathers, mothers, kings, presidents, totems, ancestral effigies, fetishes, or even anatomical parts, as the eye, for example, in Victor Hugo's poem "la Conscience" (Crapanzano 1992: 93).The self may be conceived as the absent interlocutor who is addressed as the support of ego's desire and anxiety.

The staging of healing rituals is complex and offers different supports of identification represented by the structure of the ritual itself, which allows the interaction of the devotee with priests, mediums and other devotees. The embodiment of the gods or spirits is central here as we have seen with the statue of the goddess or with the important presence of the twin sisters. Parallel to the embodiment of gods and spirits, the performers use different kinds of paraphernalia. Yet, in these Indian cases the empowerment of the performers rests on sexual conversion which evokes both Shiva and the goddess, since the god Shiva himself is sometimes described as feminine while his consort might take a masculine aggressive form which is well known to the devotees. ${ }^{19}$ The great majority of Hindu

19. This shivaite feature does not exclude vaishnavite influence, especially in Bengal where the Kali of Compassion is called Bisnu Kali. 
myths depict Shiva's sexual activity as dangerous and his chaste feminine aspect as a refuge. Sometimes, Shiva takes the form of a woman to please his consort Parvati (Doniger O'Flaherty 1973: 305). Similarly, in Bengal, devotees of the god Shiva experience sexual conversion as a part of the affects which lead to the shaping of the self. Parallel to these identifications which are supposed to be occasional, Hindu bhakti (devotion) for example, provides the devotees with ritual sequences such as darshan ${ }^{20}$ which appears as a reservoir for the most intimate fantasies, fears and hopes of the devotees. It is well known that devotion is often expressed in a sensual manner. The devotee is supposed to offer his prema (love) to the deity and thus bhava (emotion) is inherent in worship.

Healing rituals are efficacious since they involve a risk which is shared by the patient, his family and the performer. For the female devotee the risk is ontological, since it often implies the need to severe her ties with her family, in order to get healed and, in Bengal, become a priestess.

The situations I have presented offer a social space where anybody may question the goddess or the Siri family of bhutas. Yet we have seen that the two cults differ greatly: in Bengal, the goddess demands a lot from devotees but finally gives them a lot in return. In South Kanara, the Siri bhutas do not demand renunciation from their devotees, since they have themselves suffered as humans before they became bhutas. It is their suffering which allows devotees to identify with them. In both cults, however, the efficacy of the cure can be described as a transformation of an uncontrolled possession, or other illness, into a spiritual alliance with a deity. In the Siri cult, this spiritual alliance is enacted every year in front of a large audience. The presence of the audience shows that individual suffering in Tulu society is related to the matrilineal ethos, as we see when the jealousy of the twins becomes the feeling most feared. In Bengal, individual suffering is related to the context of exploitation of the subaltern communities and its consequences on the family level.

20. Darshan literally means "vision". To "see" a deity here may refer to the quite common experience of realizing the deity's presence in her image, but in this context I refer also to the stronger sense of the term, which refers to "visions" understood as a kind of miracle. 
Both examples show that, in South Asia, local communities reinvent mythic frames to allow different kinds of journeys to the Self. In my analysis of the two cults, I have stressed the verbal exchanges taking place between the devotee and the goddess, the devotee and the priestess, the devotees and the bhutas and so on. Therapeutic cults are marked by verbal transactions aiming at capturing the self through a projection on the deities, and the resulting references probably simplify a more complex process which is at work in the life stories. In these narratives, the Self points in the direction of the deity.

Therapeutic cults evoke psychoanalysis, since they allow the individual to find his or her own truth, provided that they respect the cultural chart. When we compare religious therapy to psychiatry, we generally find that the latter underestimates the importance of cultural contexts in the formation of symptoms. It seems pertinent to consider the singular ways through which, in India, individuals insert themselves into the collective idioms they use to articulate their personal experience of breakdown (Crapanzano and Garrisson 1977).

I hold that religious therapy might indeed heal, (or provoke a remission of the painful symptoms) providing there is interaction between the devotee, the deity, the medium or oracle as well as a group of devotees.

Of course, we cannot know how the self is experienced and to what extent it exists independently of its linguistic designation, but I suggest that the anthropologist can grasp at least the act of referencing, when the naming occurs, as when Parvati says "I have become the child of the goddess."

Ritual as a multi-layered practice offers room to bring emotions into a theatrical framework where it becomes possible to distance oneself from unbearable feelings. I suggest that participants, though they may be unable to formulate the rules which govern their ritual, still possess such rules (Lawson and Mc Cauley (2002). They possess an intuitive insight into the character of ritual acts, which allows them to acquire a ritual competence, and which explains why they validate some ritual innovations and refuse others. Participants thus develop a knowledge of the acceptability of ritual acts which helps them to develop a consciousness of the potential that ritual may have. 


\section{References}

Abu-Lughod, Lila. 1986. Veiled Sentiments; Honor and Poetry in a Bedouin Society. Berkeley: University of California Press.

Appadurai, Arjun. 1990. "Topographies of the self: praise and emotion in Hindu India.” In Catherine A. Lutz and Lila Abu-Lughod, eds. Language and the Politics of Emotion. Cambridge: Cambridge University Press.

Austin, John L. 1975 [1962]. How to do things with words, [first ed.Havard] Oxford: Oxford University Press.

Bateson, Gregory. 1936. Naven: A Survey of the Problems Suggested by a Composite Picture of the Culture of a New Guinea Tribe Drawn from Three Points of View. London: Cambridge University Press.

Carrin, Marine. 1986. "La fleur et l'os: symbolisme et rituel chez les Santal." Cahiers de l'Homme 26, Paris, EHESS.

--. 1997. Enfants de la Déesse. Dévotion et prêtrise féminines au Bengale. Paris: CNRS Editions/MSH.

--. 1999a."The Sacrifice of Femininity, Female Sacredness at the Hindu/ Tribal Frontier of Bengal.” In H.Tambs-Lyche, The Feminine Sacred in South Asia. Delhi: Manohar: 114-133.

--. 1999b. "Reasserting Identity through Suffering: Healing Rituals in Marine Carrin ed. Bengal and Karnataka." In Managing Distress Possession and Therapeutic Cults in South Asia: 90-115.

--. 2007. "Le meurtre symbolique des jumelles en pays tulu: la dramatisation ritualisée de la matrilinéarité." In Nicole-Claude Mathieu, Une Maison sans fille est une maison vide. La Personne et le Genre en Sociétés Matrilinéaires et/ou Uxorilocales. Paris: Éditions de la Maison des Sciences de l'Homme: 213-233.

--. 2009. "Recasting Women' agency in two therapeutic Cults of Bengal and Karnataka." In Brigitte Sébastia ed., Restoring Mental Health India, Pluralistic Therapies and Concepts. Delhi: Oxford: 125-154.

--. 2003. and Tambs-Lyche, Harald. "You don't joke with these fellows: Power and Ritual in South Canara, India." Social Anthropology, 11 (1): 23-42. Carstairs, G.Morris. and Ravi.L. Kapur, 1976. The Great Universe of Kota: Stress, Change and mental Disorder in an Indian Village. Berkeley: University of California Press.

Claus, Peter. 1971. Kinship organization of the Bunt-Nadava Caste Complex. Ph D. Thesis, Duke University.

--. 1975. "The Siri Myth and Ritual: A Mass Possession Cult of South India." Ethnology 14 (4): 45-58. 
--. 1986. "Playing Cenne: The Meanings of a Folk Game." In Stuart Blackburn and A.K. Ramanujan, Another Harmony, New Essays on the folklore of India. Berkeley: University of California Press: 265-293.

Crapanzano,Vincent. 1992. Hermes' Dilemna and Hamlet's Desire On the Epistemology of Interpretation. Cambridge Mass: Harvard University Press. --. 1977. Case Studies in Spirit Possession. New York: John Wiley.

Das,Veena and Arthur Kleinman. 2000. "Introduction" In Das, Veena , Arthur Kleinman, Mamphela Ramphele and Pamela Reynolds, Violence and Subjectivity. Delhi: Oxford University Press:1-10.

Dimock, Edward C. 1966. The Place of the Hidden Moon: Erotic Mysticism in the Vaisnava-Sahajiya Cult of Bengal. Chicago: University of Chicago Press.

Doniger O'Flaerty, Wendy. 1973. Asceticism and Eroticism in the Mythology of Shiva. London: Oxford University Press.

Dumont, Louis. 1985. "A Modified View of Our Origins: The Christian Beginnings of Modern Individualism." In Michael Carruthers, Steven Collins, and Steven Lukes, The Category of the Person. Cambridge: Cambridge University Press: 93-122.

Egnor, Margaret [now Margaret Trawick]. 1980. "On the Meaning of Sakti to Women in Tamilnadu." In S.Wadley ed. The Powers of Tamil Women, South Asian Series n6. Syracuse: Maxwell School of Citizenship and Public Affairs: 1-34.

Geertz, Clifford. 1984 [1974]. "From the Natives Point of View: On the Nature of Anthropological Understanding." In Richard A. Shweder and Robert A. LeVine, Culture Theory. Cambridge: Cambridge University Press: 123-136.

Honko, Laurie et al., eds. 1998. "The Siri Epic as performed by Gopala Naika." Folklore Fellows Communication. Helsinki: Academia Scienciarum Fennica: 265 -266.

Jakobson, Roman. 1963. Essais de Linguistique Générale. Paris: Editions de Minuit. Kakar, Sudhir. 1978. The Inner World: A Psycho-analytic study of Childhood and Society in India. Delhi: Oxford University Press.

--. 1984. Shamans, Mystics and doctors: A Psychological Inquiry into India and Its Healing Traditions. Delhi and London: Mandala Books and Unwin Paperbacks.

--. 1990. "Stories from Indian psychoanalysis: context and text." In J.W.Stigler, R.A.Shweder and G.Herdt, Cultural Psychology, Essays on comparative human development. New York: Cambridge University Press 427-445. 
--. 1999 "Clinical Work and Cultural Integration." In Vaidyanathan T.G. and J.J. Kripal, Vishnu on Freud's Desk: A reader in Psychoanalysis and Hinduism. Delhi: Oxford: 216-231.

Lawson, E. Thomas and Robert. N. McCawley. 2002. Bringing Ritual to Mind, Psychological Foundations of Cultural Forms. Cambridge: Cambridge University Press.

Lynch, Owen M. 1990. "The Social Construction of Emotion in India." In Lynch Owen M, Divine Passions. The Social Construction of Emotion in India. Berkeley: University of California Press: 3-34.

Malinowski, Bronislav. 1944. A Scientific Theory of Culture and Other Essays. Chapel Hill: University of North Carolina Press.

Marriott, McKim. 1976. "Hindu Transactions: Diversity Without Dualism." In Bruce Kapferer, Transaction and Meaning. Philadelphia: Institute for the Study of Human Issues: 109-142.

Mayaram, Shail. 1999. "Spirit Possession: Reframing Discourses of the Self and Other." In Assayag, Jackie and Gilles Tarabout eds., La Possession en Asie du Sud, Parole, Corps, Territoire. Purushatra 21. Paris: EHESS: 101-132.

Nichter, Mark. 1981. "Idioms of distress." In Culture, Medicine and Psychiatry 5: 379-408.

Obeyesekere, Gananath. 1981. Medusa's Hair: An Essay on Personal Symbols and Religious Experience. Chicago: Chicago University Press.

Rosaldo, Michelle. 1984. "Towards an Anthropology of Self and Feeling." In R.A.Shweder and R .LeVine, Culture Theory Essays on Mind, Self and Emotion. Cambridge: University Press: 137-157.

Sax, William S. 2009. God of Justice Ritual Healing and Social Justice in the Central Himalayas. Oxford: Oxford University Press.

Shweder, Richard A. and EdmundJ. Bourne. "Does the Concept of the Person Vary Cross-Culturally?” In Shweder R.A. and R.LeVine, Culture Theory. Essays on Mind, Self and Emotion. Cambridge University Press: 158-199.

Silverstein, Michael. 1976. "Shifters, linguistic categories, and cultural description." In Basso K. and H. Selby, Meaning in Anthropology. Albuquerque: University of New Mexico Press.

Spiro, Melford E. 1993. "Is the Western Conception of the Self "peculiar" within the context of the world Cultures?" Ethos 21: 107-153.

Tambiah, Stanley J. 1968 “The Magical Power of Words.” In Man, New Series 3 (2): 175-208.

Teja, J.S., B.S.Khanna, T.B. Subrahmanyam, 1970, "Possession States in Indian Patients." Indian Journal of Psychiatry, 12: 71-87.

Turner, Victor. W. 1969. The Ritual Process Structure and Anti-Structure. NewYork: Aldine De Gruyter. 